Social Work

\& Education

๑) SW\&E, 2018
Rahman, A., \& Islam, T. (2018). Analysis \& Solution of the Problems Faced by the Fresh IPE Graduates at Their Initial Career: A Case Study, Social Work and Education, Vol. 5, No. 3., pp. 76-90.

\title{
Analysis \& Solution of the Problems Faced by the Fresh IPE Graduates at Their Initial Career: A Case Study
}

Md. Asfakur Rahman, Department of Industrial Production Engineering,

Rajshahi University Engineering \& Technology, Rajshahi-6204, Bangladesh asfakurrahmansaif@gmail.com

Md. Tasminul Islam, Department of Industrial \& Production Engineering, Rajshahi University Engineering \& Technology; Rajshahi-6204, Bangladesh tasminul101@gmail.com

УДК 378.4:331]-047.37

DOI: $10.25128 / 2520-6230.18 .3 .8$
\& Abstract. Department of Industrial \& Production Engineering started its glorious journey from 2006 in of Rajshahi University of Engineering \& Technology. ; Since then approximately 250 students graduated and continuously enhancing the global quality of the department through leading discovery and innovation. Despite their shines in career, some problems come their way and make them realize that they should be more careful about them in their University life. In order of to get the regarding information, we surveyed about 100 graduates of IPE from different series. They are now working in different sectors with a different designation. Their experience about their career life will help us to find out the problems faced by the fresh IPE graduates as well as it will help us to solve the problems in our University life. We analyzed the data \& build methodology through the brainstorming process \& finally achieved our result. This will provide a way to overcome the problems faced by the fresh IPE graduates in their initial career.

Article history:

Received: September 09, 2018

1st Revision: $\quad$ October 12, 2018

Accepted: October 30, 2018

Key words: IPE, Graduates; Career; Suggestions. 


\section{Introduction}

The process of graduation helps the graduates in their career alongside his future life. So, in this time they should be more concern about their learnings. The department can provide them proper guideline and it can also modernized its education structure. For this we need to survey among the graduates. After survey we have to analysis the results. Then we have to identify the future scope and obstacles and make a conclusion of the remedy of the initial problems faced by the fresh graduates. Actually, graduate quality improvement is a very important task but it is very difficult to solve without finding the root causes. This is a long-term process \& have not felt the problem deeply yet by anybody. This article will help to all students of Department of Industrial \& Production Engineering of developing, less developed or underdeveloped countries.

\section{Literature Review}

The admission system in Engineering Universities is not so easy. A very competitive examination is held among the students who score more than $80 \%$ marks in Physics, Chemistry, Mathematics, English in A level exam. Eligible students can participate in the admission test which varies in different universities from 500 to 700 marks. Both written \& Multiple-choice questions have to be answered. The merit position of the admission test result is published based on the order of marks scores in the exam. Then, they can get themselves admitted into different programs according to their merit position \& order of choice. In this system, many students can't get admitted into their desired Engineering program. It is one of the major reasons for poor academic result as well as frustration.

The social medias are taking a lot of time from us. Students are teenagers \& they are the main victim of social media addiction. Attraction to opposite gender is one of the vital causes behind the problem. Getting rejected to love proposal, suffering from frustration, failure in scoring good result in spite of trying harder etc. deviate many students from studies. It is a responsibility of the university to help them \& guide them so that it is possible to overcome these problems at the early stage but university is immutable in this case \& only care the good students who get higher marks only. This type of discrimination \& humiliation discourages students to ask help to the university or course advisers. In this research, a continuous approach has been applied experimentally within the students who were trying hard to overcome their situation.

A few works were initiated \& successfully started a flow in different types of improvements in our university. In 2017, Hasan, M.Z. \& Dutta A. applied PDCA cycle, a concept included in TQM philosophy in order to improve personal skills of Engineering students \& successfully initiated a study on students to develop their skill to ensure better career (Hasan, Md Zahid., 2017). Hasan, Z. and Hossain, M.S. experimentally applied TQM tools to determine root causes \& used PDCA cycle concept of TQM \& successfully improved the effectiveness of Engineering students in 2018 (Hasan, Z., \& Hossain, M. S., 2018). Channar, S. H., Mehran, A. A. S., Ali, N. I., $\&$ Brohi, I. A. showed the problems that are faced by the females Postgraduate students in the universities of Jamshoro cities, Pakistan \& found a solution in their research in 2017 (Channar, S., et al., 2017). In the year 2015 Shreenivas, B., Archana, H. R., Gururaj, C., \& Ambika, K. leveraged the use of technology in the conventional teaching system, which results in improved teaching-learning process. The focus on OBE was through the use of various assessment methods in a specific course (Shreenivas, B., et al., 2015). In the year 2014 Daghan, Gökhan, and Buket Akkoyunlu examined cases on 
performance based assesment methods (PBAMs) \& enabled students to take responsibility of the method also for progress in lessons (Daghan, G., \& Buket A., 2014). Kubota, K., Terashima, K., Nakahashi, Y., \& Morioka, H. analyzed the distance learning environment in Japan \& suggested to provide different learning strategies according to the students need for their improvement in 2008 (Kubota, K., et al., 2008). In the year 2016 Miyakoshi, M. worked on a research to understand the connection between higher education as a joint development project between Egypt and Japan and ESD based on students' opinions (Miyakoshi, M., 2016). Korsah, K. G. in 2013 examine the factors that impede the academic progression of graduates from technical institutions to the Polytechnics and the Universities, reasons of not getting the appropriate level of job placement in industry \& suggested to modify the curriculum (Korsah, K., 2013). In 2016 Ali Alghail, A. A., \& Ali Mahfoodh, O. H. worked in the assessment of the academic reading difficulties encountered by international graduate students in a Malaysian university \& solved the problem (Ali Alghail, Ali Abdullah, \& Omer Hassan Ali Mahfoodh, 2016). In the year 2010 Hai-ming, H., Hai-ling, G., \& Guo-chun, H. Surveyed on Graduate Employment Difficulties and reached a solution by adjustments of schooling, strengthening the training of students comprehensive quality, solve the students conformity psychology and offering employments guidance courses (Hai-ming, Hu, Gu Hai-ling, and Hu Guo-chun, 2010). Geng-yu, W., Meng, Z., \& Jun-wu, T. Analyzed of employment difficulties of female graduate students in Engineering colleges in 2011 to solve the problem (Geng-yu, Wang, Zhang Meng, and Tong Jun-wu, 2011). In 1989 Chi, M. T., Bassok, M., Lewis, M. W., Reimann, P., \& Glaser, R. discussed that self-exploration is a solution of choosing own career, understand things easily \& solve problems instantly (Chi, Michelene T.H, et al., 1989).

\section{Methodology}

The sequences of tasks in this research are:

a survey is done to know the real problems a fresh IPE graduate face at his initial career. For this we collected information from our honorable seniors from different academic series. To contact them we used E-mail, Social apps. We created a form by the help of Google docs to collect their experience about their faced problems through internet;

after collecting the information, we created a Database by the help of Microsoft Excel software;

then with the help of Microsoft Word and Microsoft Excel we create an analysis of the survey result;

according to the survey result we selected the most voted problem and then we provide a solution of the problem by the help of multiple decision-making criteria.

\section{Results}

\section{Suggestion 1}

From the above answers in Table 1 the respondents give we can conclude to the following suggestions ${ }^{\wedge}$

i) Communication problems are faced by some of the graduates. In order to eliminate the communication problem there should be given more concern about English language practice as well as should develop the practice of extracurricular activities like joining debates, giving speech, anchoring etc. 
Challenges a fresh IPE graduate face

\begin{tabular}{|c|l|}
\hline $\begin{array}{c}\text { Serial } \\
\text { No. }\end{array}$ & \multicolumn{1}{|c|}{ Challenges they have faced } \\
\hline 01 & $\begin{array}{l}\text { If you ask the challenge for 1st career then must say "waiting for a call for } \\
\text { viva". In this point, your CV \& networking is very-very important. }\end{array}$ \\
\hline 02 & Multi-task in very short time. \\
\hline 03 & Choice of a job field that I expect to start my carrier. \\
\hline 04 & To survive inside new environment. \\
\hline 05 & To cope up in a BUET environment. \\
\hline 06 & Communication. \\
\hline 07 & English Communication with foreign management including my Dept. Head. \\
\hline 08 & $\begin{array}{l}\text { New environment with new faces. It is a very big challenge for everyone to } \\
\text { cope with that conditions. }\end{array}$ \\
\hline 09 & To manage people. \\
\hline 10 & $\begin{array}{l}\text { Garments Oriented Job Sector for IPE Graduates in BD. Hardly, there is Job } \\
\text { opportunity in other sectors for IPE Graduates. }\end{array}$ \\
\hline 11 & Not faced. \\
\hline 12 & To cope with the new environment. \\
\hline 13 & Communication problem. \\
\hline 14 & Communication problem. \\
\hline 15 & To Cope with new environment. \\
\hline 16 & For higher study. \\
\hline 17 & Presentation problem. \\
\hline 18 & Communication related problem. \\
\hline 19 & Presentation Skill. \\
\hline 20 & Communication Problem. \\
\hline 21 & For me it was hard to adapt with the industrial environment. \\
\hline 22 & To adapt with the working pressure in garments sector. \\
\hline 23 & $\begin{array}{l}\text { Mainly IPE related jobs are challenging for girls. It was hard for me to cope } \\
\text { with the working environment. }\end{array}$ \\
\hline 24 & To maintain the working pressure in new environment. \\
\hline 25 & To choose a particular sector when there was a lot of opportunities. \\
\hline 26 & To cope with new environment, new people and working pressure. \\
\hline 27 & High pressure of the industry. \\
\hline 28 & Report submission to boss. \\
\hline & \\
\hline
\end{tabular}

ii) Some of the graduates faced problem with the new workplace environment as well as in other University environment for higher studies. To eliminate the problem there should be make sure to increase the industrial visit (Minimum 1 industrial tour per year); and there should be good communication with other Universities in Bangladesh as well as foreign Universities. This will also help students to complete their higher studies at their chosen universities easily.

iii) Then comes the problem of selecting a particular sector for career. Recently Electrical and Electronic department of RUET started a trend of helping students to 
select their sector of career. They provide a choice form to the $3^{\text {rd }}$ Even Semester students and sort them for a particular career field according to their CGPA. This should be practice in our department with some modification like not only with CGPA but also with the expertness about the career field as soon as possible. This will enhance the job sectors which are suitable for IPE graduates.

iv) There should be start different projects like industrial case solving to make students experts in multi-task. This will also provide good experience of practical knowledge. This will also provide students to adapt with the working pressure in industries.

v) Management related subjects should be come in lab course to overcome the managerial related problems.

vi) Presentation related problems should be eliminated. For this, there should be at least one formal presentation in every cycle. This will provide students a better knowledge about the presentation, and development of their presentation skill.

vii) Report submission should improve by practicing the related software as formal reports in industries are mainly submitted by writing in Microsoft word, Microsoft excels etc.

vii) We know that the conservative society of Bangladesh makes some of the working sectors inappropriate for IPE graduated girls. To, minimize this problem there should be stablish an information related group to provide them the best suitable working sectors. The group should also provide them mental support and solution of the career problem.

Table 2

Environmental adaptedness of workplace

\begin{tabular}{|c|c|c|c|c|}
\hline Options & $\begin{array}{c}\text { a. Very } \\
\text { adaptable }\end{array}$ & b. Adaptable & $\begin{array}{c}\text { c. Hard to } \\
\text { adapt }\end{array}$ & $\begin{array}{c}\text { d. Very hard to } \\
\text { adapt }\end{array}$ \\
\hline Frequency & 1 & 16 & 11 & 0 \\
\hline $\begin{array}{c}\text { Frequency } \\
\text { Percentage }\end{array}$ & $3.57 \%$ & $57.14 \%$ & $39.29 \%$ & $0 \%$ \\
\hline
\end{tabular}

We can see from the figure 1 that about $57 \%$ of respondent feel that the environment of working environment for fresh graduates is adaptable. 39\% of them thinks that the environment is hard to adapt. $4 \%$ of them feel the environment for freshets is very adaptable. From this we can conclude that we are still facing problems regarding environmental adaptedness.

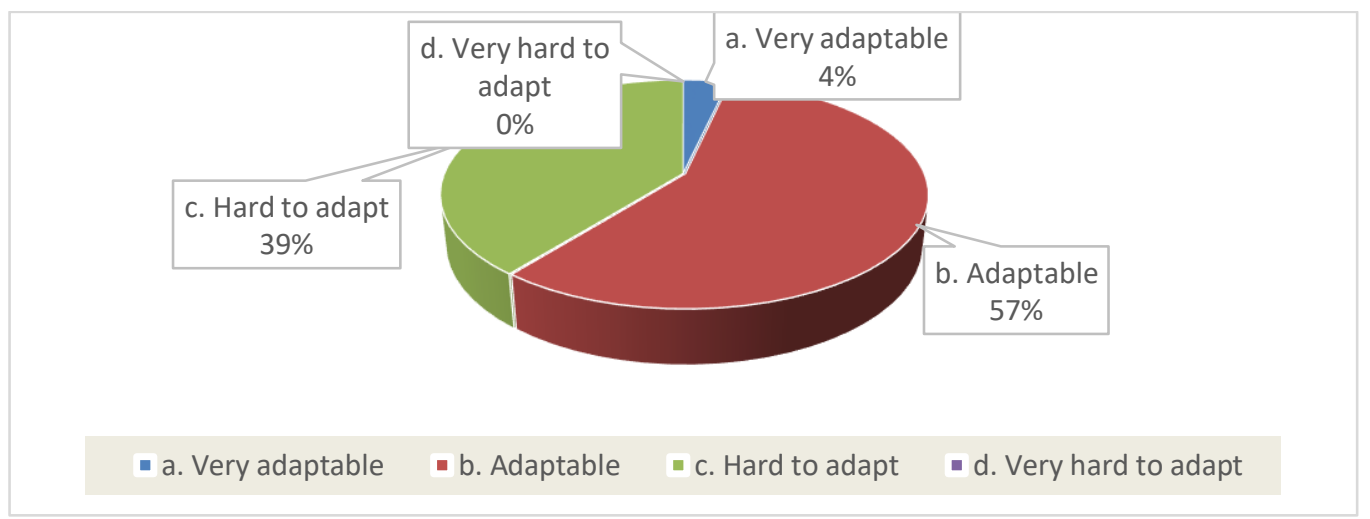

Figure 1: Pie Chart of environmental adaptedness of workplace. 


\section{Suggestion 2}

To eliminate the problem, we should make sure to increase the industrial visit (Minimum 1 industrial tour per year). As well as we should keep a good communication with industries and we should also apply our research to solve different industrial cases.

Table 3

Communication Problem

\begin{tabular}{|c|c|c|c|c|}
\hline Options & a. Not faced & $\begin{array}{c}\text { b. Often } \\
\text { faced }\end{array}$ & $\begin{array}{c}\text { c. Faced a } \\
\text { lot }\end{array}$ & $\begin{array}{c}\text { d. Faced but overcome } \\
\text { easily }\end{array}$ \\
\hline Frequency & 4 & 5 & 2 & 17 \\
\hline $\begin{array}{c}\text { Frequency } \\
\text { Percentage }\end{array}$ & $14.29 \%$ & $17.86 \%$ & $7.14 \%$ & $60.71 \%$ \\
\hline
\end{tabular}

As described in question 1 suggestion section (Suggestion i) communication problem is many of the respondents common problem. Selective perception, Language, Silence, Cultural barrier, Gender difference are the most common barriers of communication. From the figure 2 we can see that $61 \%$ of the respondents faced the communication problem but they overcome that easily, $18 \%$ of them often faced, $7 \%$ faced a lot and the left $14 \%$ respondent didn't faced the problem.

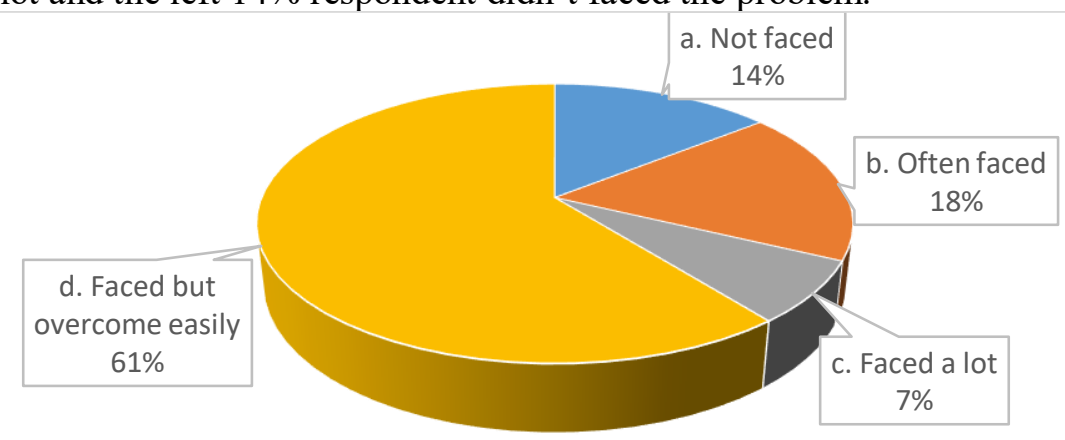

$$
\text { - a. Not faced } \quad \text { b. Often faced } \quad \text { c. Faced a lot } \quad \text { d. Faced but overcome easily }
$$

Figure 2: Pie chart of communication problem

\section{Suggestion 3}

In order to solve the communication problem some steps should be taken. Such as, Practicing English language as most of the formal communication are done by English. We should come forward from the cultural barrier. There should also develop the practice of extracurricular activities like joining debates, giving speech, anchoring in different programs etc.

The good knowlwdge of different software makes an IPE graduate more smart. From the Table 4 and Figure 3 we can see that $100 \%$ of the respondent thinks that Students should learn Microsoft Excel, then comes the importance of learning Microsoft Word and the percentage of importance is $92.86 \%$, importance of learning AutoCAD is 50\%, then comes the SolidWorks and Microsoft Access both of them are equally important and the importance is $39.29 \%$. Importance of learning Microsoft PowerPoint is $17.86 \%$, MATLAB $10.71 \%, \mathrm{C} / \mathrm{C}++$ programming and LINDO both 
7.14\%. Application based soft, Photoshop \& illustrator, MS project, Microsoft Visio are equally $3.57 \%$ important.

Table 4

Important softwares to learn

\begin{tabular}{|c|c|c|c|}
\hline \multicolumn{2}{|c|}{ Options } & Frequency & $\begin{array}{l}\text { Frequency } \\
\text { Percentage }\end{array}$ \\
\hline \multicolumn{2}{|c|}{ a. Microsoft Excel } & 28 & $100.00 \%$ \\
\hline \multicolumn{2}{|c|}{ b. Microsoft word } & 26 & $92.86 \%$ \\
\hline \multicolumn{2}{|c|}{ c. Microsoft Access } & 11 & $39.29 \%$ \\
\hline \multicolumn{2}{|c|}{ d. MATLAB } & 3 & $10.71 \%$ \\
\hline \multicolumn{2}{|c|}{ e. AutoCAD } & 14 & $50.00 \%$ \\
\hline \multicolumn{2}{|c|}{ f. SolidWorks } & 11 & $39.29 \%$ \\
\hline \multicolumn{2}{|c|}{ g. LINDO } & 2 & $7.14 \%$ \\
\hline \multicolumn{2}{|c|}{ h. $\mathrm{C} / \mathrm{C}++$ programming } & 2 & $7.14 \%$ \\
\hline \multirow{5}{*}{ i. } & Photoshop \& illustrator & 1 & $3.57 \%$ \\
\hline & Microsoft Visio & 1 & $3.57 \%$ \\
\hline & MS project & 1 & $3.57 \%$ \\
\hline & Application based soft & 1 & $3.57 \%$ \\
\hline & Microsoft PowerPoint & 5 & $17.86 \%$ \\
\hline
\end{tabular}

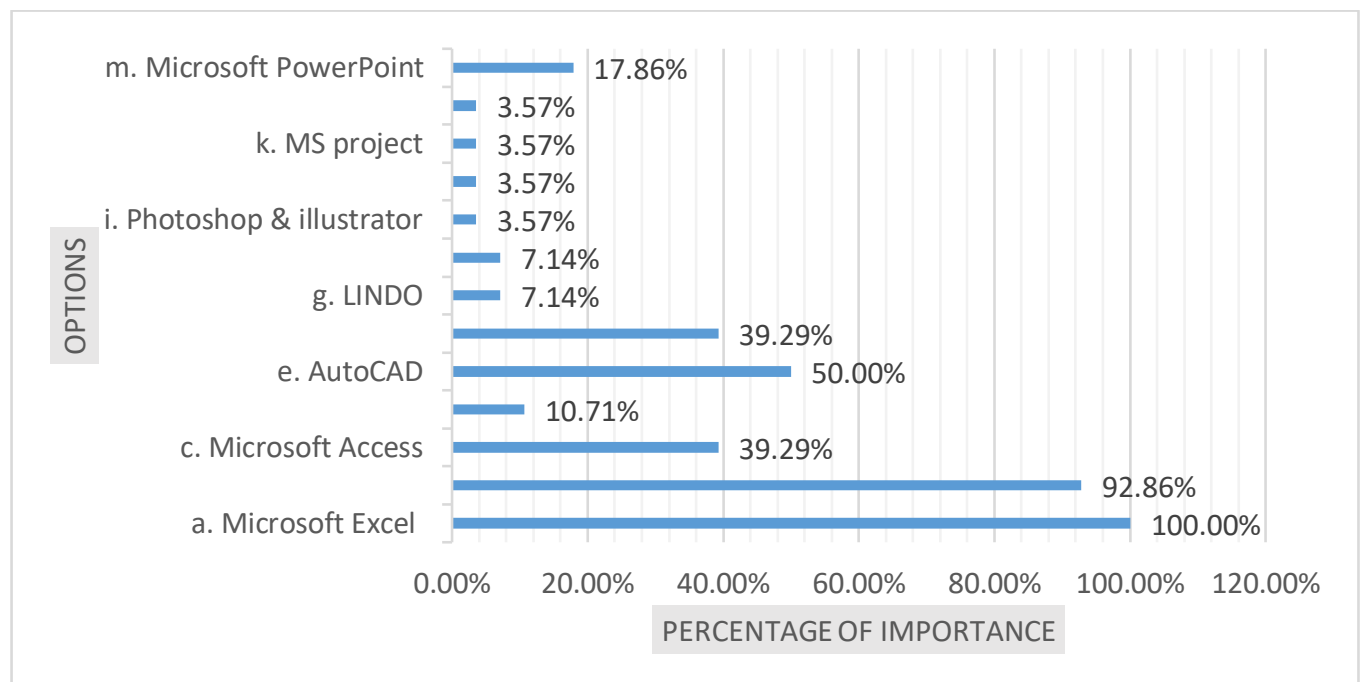

Figure 3: Bar chart of important softwares to learn

\section{Suggestion 4}

From the above description we now know the importance of learning softwares. From their importance level given by the respondents we can serial them from highly important to less important. The serial is- Microsoft Excel > Microsoft Word > AutoCAD > SolidWorks ,Microsoft Access > Microsoft PowerPoint > MATLAB ,C/C++ Programming > LINDO > Application based soft, Photoshop \& illustrator, MS project, Microsoft Visio. 
There should be given more concern about learning of the softwares by arranging seminars, workshops, and competitions. This all will encourage students to learn the important softwares.

Table 5

\section{Condition of lab facilities}

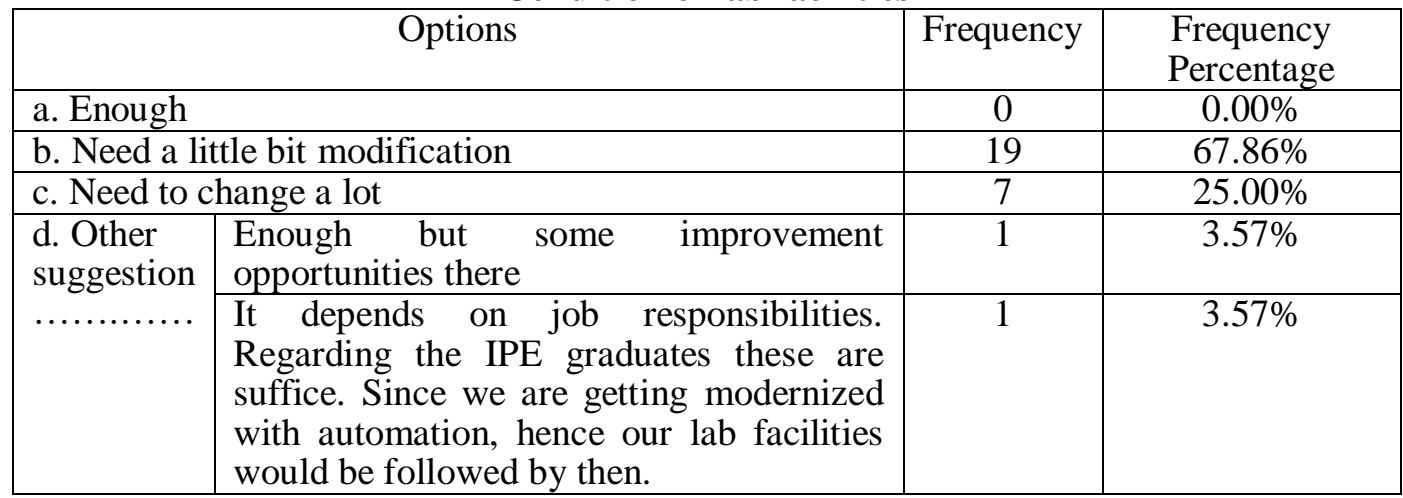

Lab facilities are a very important thing to the whole graduation process. A little bit of lack in this section causes a lot of learning gap. Figure 4 shows that the lab facilities need a little bit modification and this is voted by $68 \%$ graduated respondents. $26 \%$ respondent there needs to change a lot. $4 \%$ said that the facilities are enough but there are some important opportunities. Later 3\% said that the lab facilities should be modernized.

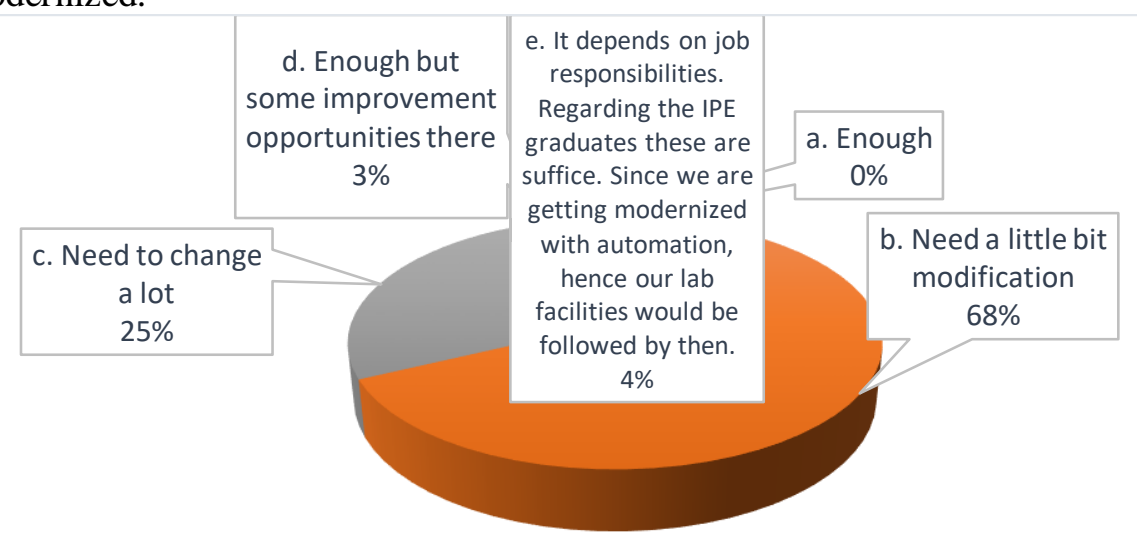

Figure 4: Pie chart of condition of lab facilities

\section{Suggestion 5}

From the Table 6 and Figure 5, it seems that our lab facilities needs to improve and modernized. This could be done through enriching our labs with modern equipment, creating new labs according to the latest concepts of IPE tools. From the analysis of question 5 we saw that there should be added some important software learning lab courses. Most of the departments of renowned universities have their own lab trainee who perfectly helps the students regarding the needs of the department, but we don't have any trainee. So, we should assign lab trainee as soon as possible. This all will be helpful to improve the lab facilities. 


\section{Problems for Session Overdue}

Table 6

\begin{tabular}{|c|c|}
\hline $\begin{array}{l}\text { Serial } \\
\text { No. }\end{array}$ & Problems they have faced for session overdue \\
\hline 01 & $\begin{array}{l}\text { I have avoided to overdue session. However, in this case, learning was missed } \\
\text { and scold by boss is must. A negative mark adds with your personality. } \\
\text { Because in career life, discipline is very important. }\end{array}$ \\
\hline 02 & We should more smart in our speech, body language, dress code \& loyalty. \\
\hline 03 & Your juniors of other university will lead you in the job. \\
\hline 04 & N/A \\
\hline 05 & $\begin{array}{l}\text { I am entering into the job market } 1 \text { year later, while some of my colleague are } \\
\text { actually my junior. But, I think it's not a big deal. }\end{array}$ \\
\hline 06 & Timing. \\
\hline 07 & $\begin{array}{l}\text { Got job before result published, so no major problem faced due to } 5 \text { months } \\
\text { delay the session. }\end{array}$ \\
\hline 08 & Actually I didn't face this sort of problem because we passed away on due date. \\
\hline 09 & There are so many problem for session overdue like the unhappiness of boss. \\
\hline 10 & Initial lagging in competition. \\
\hline 11 & N/A \\
\hline 12 & $\begin{array}{l}\text { For session overdue, the others varsity students can easily lead you in the job } \\
\text { sector. }\end{array}$ \\
\hline 13 & Timing of job circular. \\
\hline 14 & Not faced any problem for session overdue. \\
\hline 15 & Passed later and as a result joined later in job. \\
\hline 16 & $\begin{array}{l}\text { So many problems were created for session overdue. Mainly in job sector we } \\
\text { were missed so many job circular for session overdue. }\end{array}$ \\
\hline 17 & Passed later. \\
\hline 18 & No Problem. \\
\hline 19 & Passed later and as a result started job later \\
\hline 20 & $\begin{array}{l}\text { Juniors from others varsity passed quickly and as a result we competition were } \\
\text { increased in job sector. }\end{array}$ \\
\hline 21 & Promotion problem compare to other university graduates. \\
\hline 22 & $\begin{array}{l}\text { The main problem was timing. But personally, I didn't face any problem for } \\
\text { session overdue. }\end{array}$ \\
\hline 23 & Got job so early, so I didn't face any problem for session overdue. \\
\hline 24 & $\mathrm{~N} / \mathrm{A}$ \\
\hline 25 & It wasn't a big problem for me at all. \\
\hline 26 & Mainly frustration is the major problem of session overdue. \\
\hline 27 & Family pressure and also mental pressure. \\
\hline 28 & Delay to get job \\
\hline
\end{tabular}

\section{Suggestion 6}

From the Table 7 we can see that almost every respondents faced different problems for session overdue. The only solution of this problem is to remove all of the 
session overdue remains. This can be done through proper managements of the university authorities.

Table 7

Suggestions for the syllabus of IPE

\begin{tabular}{|c|c|}
\hline $\begin{array}{l}\text { Serial } \\
\text { No. }\end{array}$ & Suggestions for the syllabus of IPE \\
\hline 01 & $\begin{array}{l}\text { Please add, Decision making in PPC (production planning \& control), ref book- } \\
\text { Fundamentals of Management Science, Sixth Edition, by- Turban, Meredith. Profit } \\
\text { planning in accounting, Business communication- very important \& required for } \\
\text { whole career life, way of negotiation, formal processes, engineering applications } \\
\text { like HVAC, PLC, TIS (Technical information system) etc. }\end{array}$ \\
\hline 02 & $\begin{array}{l}\text { I think: } \\
\text { 1. Physics, chemistry, math can be merged as much as possible instead of } \\
\text { several semester. } \\
\text { 2. Supply chain management, Operations management, Organization behavior, } \\
\text { Industrial \& Business Management should be extended. } \\
\text { 3. Industrial attachment time should be extended } 4 \text { week to } 12 \text { week. }\end{array}$ \\
\hline 03 & $\begin{array}{l}\text { Lab facilities of control and automation, Simulation should be made more } \\
\text { effective. Some practical industry base problems should be practice so that a } \\
\text { graduate can understand the problems in his job life easily and trace it easily. }\end{array}$ \\
\hline 04 & ( \\
\hline 05 & Need slight modification. \\
\hline 06 & $\begin{array}{l}\text { Be Updated in industrial Problem, more focus on communication, software } \\
\text { related topics. }\end{array}$ \\
\hline 07 & $\begin{array}{l}\text { Excellent, some chapter may be included like Lean Management, Six Sigma } \\
\text { Management, Systematic Problem Solving Tools etc. }\end{array}$ \\
\hline 08 & $\begin{array}{l}\text { There is no comment regarding the overall syllabus of IPE but some Industrial } \\
\text { Engineering Tools like as Lean Manufacturing, 5S, TPM, TQM, JIT, POKA- } \\
\text { YOKE etc. could be taught separately by initiating } 1 \text { or } 2 \text { credits so that the } \\
\text { students get acquainted with these in broadly before entrance into job fields. }\end{array}$ \\
\hline 09 & No. \\
\hline 10 & $\mathrm{~N}$ \\
\hline 11 & \\
\hline 12 & $\begin{array}{l}\text { is the attachment should be } \\
\text { at related course ... }\end{array}$ \\
\hline 13 & $\begin{array}{l}\text { Need some modification about physics, chemistry course and I think credit } \\
\text { should be decrease for those courses. }\end{array}$ \\
\hline 14 & nt related cours \\
\hline 15 & $\begin{array}{l}\text { ctical life related course like Organizational Behavior, } \\
\text { tc. }\end{array}$ \\
\hline 16 & difications are needed in our IPE course. \\
\hline 17 & \\
\hline 18 & about Six Sigma, $\mathrm{n}$ \\
\hline 19 & \\
\hline 20 & \\
\hline 21 & \\
\hline
\end{tabular}




\begin{tabular}{|c|l|}
\hline 22 & Some practical job related problems should be practice in graduate level. \\
\hline 23 & We should focus on real life problems. For this industrial tour needed (I think). \\
\hline 24 & $\begin{array}{l}\text { Non departmental courses should be minimized and departmental courses } \\
\text { should be increased. }\end{array}$ \\
\hline 25 & Presentation related context should add in the syllabus. \\
\hline 26 & N/A \\
\hline 27 & Attachment duration should be increased. \\
\hline 28 & No \\
\hline
\end{tabular}

From the Table 8 we can conclude to the following changes to our syllabus-

i) Decision making in PPC (production planning \& control), ref. bookFundamentals of Management Science, Sixth Edition, by- Turban, Meredith should add in the syllabus.

ii) Profit planning in accounting, Business communication related subjects and courses should add in the syllabus.

Iii) Physics, chemistry, math should be merged as much as possible instead of several semester and Supply chain management, Operations management, Organization behavior, Industrial \& Business Management should be extended in several semester.

iv) Lab facilities of control and automation, Simulation should be made more effective. Some practical industry base problems should be practice so that a graduate can understand the problems in his job life easily and trace it easily.

v) Industrial attachment time should be extended as much time as possible (at least 6 to 12 weeks).

vi) Software related topics and courses should be add in the syllabus.

vii) Special care should be taken on Lean Management, Six Sigma Management, Systematic Problem Solving Tools etc.

viii) There should be add some Industrial Engineering Tools like as Lean Manufacturing, 5S, TPM, TQM, JIT, POKA-YOKE etc. could be taught separately by initiating 1 or 2 credits so that the students get acquainted with these in broadly before entrance into job fields.

Table 8

\section{Suggestion regarding our whole graduation system}

\begin{tabular}{|c|l|}
\hline $\begin{array}{c}\text { Serial } \\
\text { No. }\end{array}$ & Suggestion regarding our whole graduation system \\
\hline 01 & $\begin{array}{l}\text { Its good design, no doubt, although many courses seems very irrelevant \& } \\
\text { painful, but in few cases those are important. So we should read all with equal } \\
\text { importance. To be specific our courses can include above terms which must aid } \\
\text { IPE Engineers guaranteed. Thank you. }\end{array}$ \\
\hline 02 & $\begin{array}{l}\text { 1. Complete formal dress at least one day in a cycle must be ruled. } \\
\text { 2. Presentation in every cycle after 2nd semester (no group, one topic one } \\
\text { student). }\end{array}$ \\
\hline 03 & $\begin{array}{l}\text { Industry based jobs are more practical than theoretical. So we need to } \\
\text { understand the every problem practically. }\end{array}$ \\
\hline 04 & N/A \\
\hline 05 & N/A \\
\hline 06 & N/A \\
\hline
\end{tabular}




\begin{tabular}{|c|c|}
\hline 07 & $\begin{array}{l}\text { Students should enhance their Leadership Skill, Communication Skill, } \\
\text { Proactiveness through voluntary participatory work (not hampering the class \& } \\
\text { study, it's a parallel task). Now please try, take challenges \& do your best! }\end{array}$ \\
\hline 08 & $\begin{array}{l}\text { It is a common practice in our graduation system to go through the bookish } \\
\text { knowledge whereas the job field is completely different than it. Students have } \\
\text { to face a lot of problems during job lives which are not embedded into the } \\
\text { books. Some seminars, workshops, idea contest etc. could be run along with } \\
\text { academic activities to enhance and garnish the knowledge of students so that } \\
\text { they can compete with outsiders at very beginning of their job lives. }\end{array}$ \\
\hline 09 & $\begin{array}{l}\text { There should be some modification in graduation system. I think the more } \\
\text { materialistic education should be introduced so that in our real job life we can } \\
\text { think that we have already done that in little scale. }\end{array}$ \\
\hline 10 & Need to increase the communication with industrial sector and corporate sector. \\
\hline 11 & N/A \\
\hline 12 & $\begin{array}{l}\text { Need more lab facilities and new machine in the machine shop like CNC } \\
\text { machine, etc. }\end{array}$ \\
\hline 13 & During your BSc course, you should focus on your target and work for it. \\
\hline 14 & N/A \\
\hline 15 & $\begin{array}{l}\text { We need more practical knowledge. For this, I think some modification needed } \\
\text { in our courses. Thanks. }\end{array}$ \\
\hline 16 & $\begin{array}{l}\text { I want to suggest to the new graduate's, focus your target and try your best to } \\
\text { fulfill it. That's all .Thanks. }\end{array}$ \\
\hline 17 & I think some improvement needed in our lab facilities. \\
\hline 18 & $\begin{array}{l}\text { Mainly we need to improve our bonding. It's most important matter for IPE } \\
\text { related jobs. Thanks. }\end{array}$ \\
\hline 19 & No thanks. \\
\hline 20 & We need more practical knowledge for this we need more time in attachment. \\
\hline 21 & $\begin{array}{l}\text { The system should provide every student good at communication and make } \\
\text { himself reasonable for his position. }\end{array}$ \\
\hline 22 & $\begin{array}{l}\text { Need more knowledge about industry, factory and other job sectors. So that, } \\
\text { one can easily cope with the new environment of job place. }\end{array}$ \\
\hline 23 & $\begin{array}{l}\text { Some modification needed - } \\
\text { 1. Physics, Chemistry related courses should minimize. } \\
\text { 2. Seminar, workshop should increase. }\end{array}$ \\
\hline 24 & Need more seminars and workshops on IPE related topics. \\
\hline 25 & $\begin{array}{l}\text { Co-curricular activities should give more concern and practical knowledge } \\
\text { should develop. }\end{array}$ \\
\hline 26 & $\begin{array}{l}\text { I think our department need more club to practice our course related practical } \\
\text { problems. } \\
\text { Need more conference and workshops on our courses. }\end{array}$ \\
\hline 27 & $\begin{array}{l}\text { Presentation and report submission are the most important matter for promotion } \\
\text { in the industry .so I think more importance needed for those issues. }\end{array}$ \\
\hline 28 & N/A \\
\hline
\end{tabular}

From the Table 14 we can take the following decisions- 
i) Complete formal dress at least one day in a cycle must be ruled.

ii) Presentation in every cycle after 2nd semester (no group, one topic one student).

iii) Students should understand the every problem practically.

iv) Students should enhance their Leadership Skill, Communication Skill, Proactiveness through voluntary participatory work, practicing co-curricular activities (not hampering the class \& study, it's a parallel task).

v) Some seminars, workshops, idea contest etc. could be run along with academic activities to enhance and garnish the knowledge of students so that they can compete with outsiders at very beginning of their job lives.

vi) More materialistic education should be introduced so that in our real job life we can think that we have already done that in little scale.

vii) Need to increase the communication with industrial sector and corporate sector.

viii) The graduates must focus on his/her target and try his/her best to fulfill it.

ix) Bonding among the graduates and current students must be improved through organizing and attending different programs.

$\mathrm{x}$ ) Our department need more club to practice our course related practical problems as well as need to arrange more conference and workshops on our courses. xi) The system should provide every student good at communication and make himself reasonable for his position.

\section{Result}

The following steps are the result of our research-

1. There should be given more concern about English language practice as well as should enhance their Leadership Skill, Communication Skill, Proactiveness through voluntary participatory work, practicing co-curricular activities (not hampering the class \& study, it's a parallel task).

2. There should be make sure to increase the industrial visit (Minimum 1 industrial tour per year); and there should be good communication with other Universities in Bangladesh as well as foreign Universities. This will also help students to complete their higher studies at their chosen universities easily.

3. Recently Electrical and Electronic department of RUET started a trend of helping students to select their sector of career. They provide a choice form to the $3^{\text {rd }}$ Even Semester students and sort them for a particular career field according to their CGPA. This should be practice in our department with some modification like not only with CGPA but also with the expertness about the career field as soon as possible. This will enhance the job sectors which are suitable for IPE graduates.

4. There should be start different projects like industrial case solving to make students experts in multi-task. This will also provide good experience of practical knowledge. This will also provide students to adapt with the working pressure in industries.

5. Management related subjects should be come in lab course to overcome the managerial related problems.

6. There should be at least one formal presentation in every cycle (not in a group but individually). This will provide students a better knowledge about the presentation, and development of their presentation skill. If possible there should be added a 
mandatory presentation in every Lab course. Complete formal dress must be ruled in this sessions.

7. Report submission should improve by practicing the related software; as formal reports in industries are mainly submitted by using software like Microsoft word, Microsoft excel etc.

8. There should be stablish an information related group to provide female students the best suitable working sectors. The group should also provide them mental support and solution of the career problem.

9. Important softwares like Microsoft Excel, Microsoft Word, AutoCAD, SolidWorks, Microsoft Access, Microsoft PowerPoint, MATLAB, C/C++ Programming, LINDO, Application based soft, Photoshop \& illustrator, MS project, Microsoft Visio must be given priority in software relates labs. If needed there should add new lab course regarding the mentioned softwares. There should be given more concern about learning of the softwares by arranging seminars, workshops, and competitions. This all will encourage students to learn the important softwares. We should also increase the existing Lab facilities.

10. Session overdue problem must be eliminated through proper managements of the university authorities.

11. There should be arrange an encouragement program on CGPA at the beginning of university life. Students should be encouraged to achieve a good CGPA and the teachers and course advisers should be more careful about the student's response in learning.

12. The graduation system should be more practical and relatively more modernized. There should also arrange career related seminar, workshop etc. in a regular basis.

13. Bonding among the graduates and current students must be improved through organizing and attending different programs.

For syllabus this changes are resulted-

14. Decision making in PPC (production planning \& control), ref. bookFundamentals of Management Science, Sixth Edition, by- Turban, Meredith should add in the syllabus.

15. Profit planning in accounting, Business communication related subjects and courses should add in the syllabus.

16. Physics, chemistry, math should be merged as much as possible instead of several semester and Supply chain management, Operations management, Organization behavior, Industrial \& Business Management should be extended in several semester.

17. Lab facilities of control and automation, Simulation should be made more effective. Some practical industry base problems should be practice so that a graduate can understand the problems in his job life easily and trace it easily.

18. Industrial attachment time should be extended as much time as possible (at least 6 to 12 weeks).

19. Software related topics and courses should be added in the syllabus.

20. Special care should be taken on Lean Management, Six Sigma Management, and Systematic Problem-Solving Tools etc.

21. There should be add some Industrial Engineering Tools like as Lean Manufacturing, 5S, TPM, TQM, JIT, POKA-YOKE etc. could be taught separately by initiating 1 or 2 credits so that the students get acquainted with these in broadly before entrance into job fields. 


\section{Conclusions}

We did our survey on 28 IPE graduates this is only $11.20 \%$ of total graduates. If we did it with the whole $100 \%$ graduates we could reach a better solution than this is. But the sampling was random and they are from different series and works in different sectors as well as different institutions. Therefore, the most important problems are identified and we tried to project a solution as result of our research. This step of our result should employ in our graduation system with some modification and further research.

\section{References}

Hasan, Md Zahid. (2017). "Personal Skill development by Applying 'KAIZEN': An Experimental Case Study." Asian Journal of Mathematical Sciences (AJMS) 1.06

Hasan, Z., and M. S. Hossain. (2018). "Improvement of Effectiveness by Applying PDCA Cycle or Kaizen: An Experimental Study on Engineering Students." Journal of Scientific Research 10.2, 159-173.

Channar, Sheeba Hussain, et al. (2017). "Assesment of problems faced by female post graduate students: A case study of Jamshoro city universities." Engineering Technologies and Applied Sciences (ICETAS), 2017 4th IEEE International Conference on. IEEE.

Shreenivas, B., et al. (2015). "Leveraging The Assesment Methods For Outcome Based Education." Journal of Engineering Education Transformations, 331-334.

Daghan, Gökhan, and Buket Akkoyunlu. (2014). "A Qualitative Study about Performance Based Assesment Methods Used in Information Technologies Lesson." Educational Sciences: Theory and Practice 14.1, 333-338.

Kubota, Kenichi, et al. (2008). "Analyzing learning environments of distance education in Japan." Distance Learning and the Internet Conference.

Miyakoshi, Maiko. (2016). "Higher Education and Development in Egypt: Exploratory case study of the perception of E-JUST students and graduates."

Korsah, Kweku Gyano. (2013). Academic progression of graduates from technical institutions in Ghana to tertiary institutions: The case of Cape Coast technical institute. Diss. University of Cape Coast.

Ali Alghail, Ali Abdullah, and Omer Hassan Ali Mahfoodh. (2016). "Academic reading difficulties encountered by international graduate students in a Malaysian university." Issues in Educational Research 26.3, 369.

Hai-ming, Hu, Gu Hai-ling, and Hu Guo-chun. (2010). "Survey and Consideration of Graduate Employment Difficulties [J]." China Construction Education Z 6.

Geng-yu, Wang, Zhang Meng, and Tong Jun-wu. (2011). "Analysis of employment difficulties of female graduate students in Engineering college and solutions [J]." Journal of Jiamusi Education Institute 2, 336.

Chi, Michelene TH, et al. (1989). "Self-explanations: How students study and use examples in learning to solve problems." Cognitive science 13.2, 145-182. 
